\title{
活性酸素, 過酸化脂質の生成と消去機構
}

\section{藤田 直, 藤本 陽子}

\section{I.はじめに}

活性酸素, フリーラジカル, 過酸化脂質といら言葉が 生体現象の中で今日盛んに用いられるようになってき た. それは活性酸素, 過酸化脂質が種々の疾病に関与し ていることが指摘され, 生体において重要な役割を果た していることが解明されつつある結果であろら．しかし ながら,この分野における研究はほとんどが現象論に終 始することが多く, 分子レベルでの研究は困難を極めて いる.

in vitro では活性酸素, 脂質過酸化反応の実験系は, いろいろな角度から検討しやすく, また結果も多く得ら れている. しかし in vivoにその結果をすぐ適用して判 断することは非常に危険である. それは活性酸素, 過酸 化脂質生成時の環境が異なること, いずれもその評価は 指標值であって, 絶対量を論じていないことである.

本稿では活性酸素と過酸化脂質の生成と消去について 臓器, 細胞レベルから基礎的および応用面からの概説を 試みたい。

\section{II. 活性酸素の生体組織での生成と消去}

酸素は周期律法では第 $\mathrm{U}$ 族に属し，原子番号は 8 であ り, 8 個の原子をもっている. 通常電子は 2 つが対に なって存在しているのに対し，対にならず一つだけ離れ て存在する場合がある.これがフリーラジカルで反応性 が高い. 電子は対になっているのが安定で, 不対電子は 一般に不安定で, 対をなすために相手から電子をうばい, 自らは対をつくり安定になろらとする性質が強い.

酸素分子は次のように対をなしていない不対電子が 2 個存在する.

大阪薬科大学衛生化学教室

（干580 大阪府松原市河合2-10-65）

原稿受理日：1991年11月 6 日

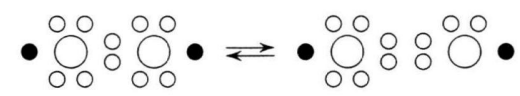

・印が対をつくっていない不対電子であり，酸素分子 はビラジカル (biradical) といえる.酸素分子が体の中 に入ると，次々に他の物質から電子をらばい，より反応 性に富む不安定な化学種に変化してゆく.すなわら酸素 はラジカルを 2 つ持っていて，そこに電子が 1 個入って くるとラジカルの性質が片方だけ消され，そのかわりも ら一方のラジカルの性質が強くなり, 弱酸性で解離して アニオンになる。これがスーパーオキシドアニオン $\left(\mathrm{O}_{2}{ }^{-}\right)$であり, 単にスーパーオキシドと称している.

活性酸素にはラジカルとラジカルでないものがある. 前者は反応性の高いものからヒドロキシラジカル $(\cdot \mathrm{OH})$, アルコキシラジカル $(\mathrm{LO} \cdot)$, ペルオキシラジ カル $(\mathrm{LOO} \cdot)$, ヒドロペルオキシラジカル $(\mathrm{HOO} \cdot)$, 二 酸化窒素 $\left(\mathrm{NO}_{2} \cdot\right)$, スーパーオキシドなどである. 後者 の非ラジカルグループには, 一重項酸素 $\left({ }^{1} \mathrm{O}_{2}\right)$, オゾン $\left(\mathrm{O}_{3}\right)$, 過酸化水素 $\left(\mathrm{H}_{2} \mathrm{O}_{2}\right)$, 脂質ヒドロペルオキシド (LOOH) などである.

脂質ヒドロペルオキシドは後述する過酸化脂質であ る. 生体内で重要なフリーラジカルはほとんど酸素を含 むもので活性酸素といっているが，時にはフリーラジカ ルと同一視している場合がある. しかし薬物によっては 生体で代謝をらけラジカルを生成して毒性を示するのが ある、例えば農薬のパラュートラジカルや四塩化炭素か ら生成されるトリクロルメタンラジカル $\left(\cdot \mathrm{CCl}_{3}\right)$ は炭 素部がラジカル化しているフリーラジカルであって活性 酸素ではない. 従って活性酸素, フリーラジカルを論じ る場合, 両者をよく整理して考察しないとまぎらわしく なってくる.

さて組織細胞レペルに影響を及ぼすとみられる活性酸 素には, フリーラジカルとして $\mathrm{O}_{2}{ }^{\circ}, \cdot \mathrm{OH}$, 非ラジカル 
として $\mathrm{H}_{2} \mathrm{O}_{2}$ がある（その他 10 数種類の活性酸素, フ リーラジカルが存在するが省略する).

生体系では $\mathrm{O}_{2}{ }^{-}$の生成はキサンチン酸化酵素, アル デヒド酸化酵素, NAD (P) H 酸化酵素などによる酵素 的反応による場合と，パラコートをはじめとする薬物の 酸化により生成するラジカルによって, 酸素分子が一電 子還元をらけ, $\mathrm{O}_{2}{ }^{-}$が生成される非酵素的反応によって 誘導されることは定説になっているが, 活性酸素生成後 の作用機序については, 汪とんど明らかにされていない.

最近注目されているのが虚血一再灌流時におけるキサ ンチンオキシダーゼの活性化である. Granger ら ${ }^{1)}$ は, 虚血一再灌流時に発生する活性酸素は $\mathrm{O}_{2}{ }^{-}$であるとい ら. その機序は虚血時に ATP の分解が促進され, ヒポ キサンチンに至る. 再血流時はヒポキサンチンを基質と してキサンチンオキシダーゼおよび再血流によって豊富 に供給される酸素とによって $\mathrm{O}_{2}{ }^{\top}{ }^{\top}$ が生成される（図 1).さらにキサンチンを基質にして酸素とキサンチン オキシダーゼにより $\mathrm{O}_{2}{ }^{-}$, 尿酸が生成される. 虚血時の キサンチンデヒドロゲナーゼからオキシダーゼへの変換 機構は現在明らかにされていない.キサンチンオキシ ダーゼは動物種, 臓器によりその活性に差があり, ヒト および家鬼の脳や心筋のキサンチンデヒドロゲナーゼ は, 虚血時, オキシダーゼに変換されないが, 肝のそれ は変換されるとい522. 一方，キサンチンから尿酸が発 生する過程には, キサンチンデヒドロゲナーゼも関与す るが，この反応は分子状の酸素は必要とせず，NAD の 存在下で進行する.

虚血により細胞内エネルギー代謝の機能が低下してく
る. この原因としては, ミトコンドリア, 細胞膜の障害 の結果, $\mathrm{Ca}^{2+}$ が大量に膜内に流入し, 代謝機能の低下 を引き起こすものと考えられている3). 虚血一再灌流に 際し，CoQ $\mathrm{C}_{10}$ を前投与するとミトコンドリアの呼吸調節 能および $\mathrm{P} / \mathrm{O}$ 比は $\mathrm{CoQ}_{10}$ 投与群では正常值に回復し， また， $\mathrm{Ca}^{2+}$ 流入も $\mathrm{CoQ}_{10}$ 投与により抑制されることが わかった.このよらな場合，ミトコンドリアの過酸化脂 質の生成は完全に抑制されたことから，ミトコンドリア の機能障害は脂質過酸化により誘導されること,さらに $\mathrm{CoQ}_{10}$ が in vivo で抗酸化的に作用していることを Kawasaki ら ${ }^{4)}$ は明らかにした。ささらに，彼らは動物モ デルによる虚血一再灌流の実験で $\alpha$-トュフェロール, グルタチオンの含量低下が in vivoにおける脂質過酸化 反応の結果であると指摘している5). 一方, Halliwell ${ }^{6)}$ は, 組織中の過酸化脂質の増量が認められても, そのこ とが病態の開始に拈けるフリーラジカルの関与を意味す るものではないことを報告している．このように細胞障 害が過酸化脂質の生成後におこるのか, それともそこに 至る過程で開始されるのか未だ解明されていない.

Nordström $5^{7)}$ は, 虚血一再灌流時の障害に対して キサンチンオキシダーゼの阻害剤であるアロプリノール を投与すると, その障害が抑制されることから虚血一再 灌流障害にヒポキサンチンーキサンチンオキシダーゼの 系が関与していることを認めた．さらに，Yoshikawa

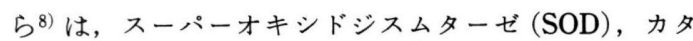
ラーゼを併用することにより $\mathrm{O}_{2}{ }^{-}$および $\mathrm{H}_{2} \mathrm{O}_{2}$ を消去 して, 反応性の高い・OH の産生を阻止することに よって組織細胞障害をより効果的に防御できることを報

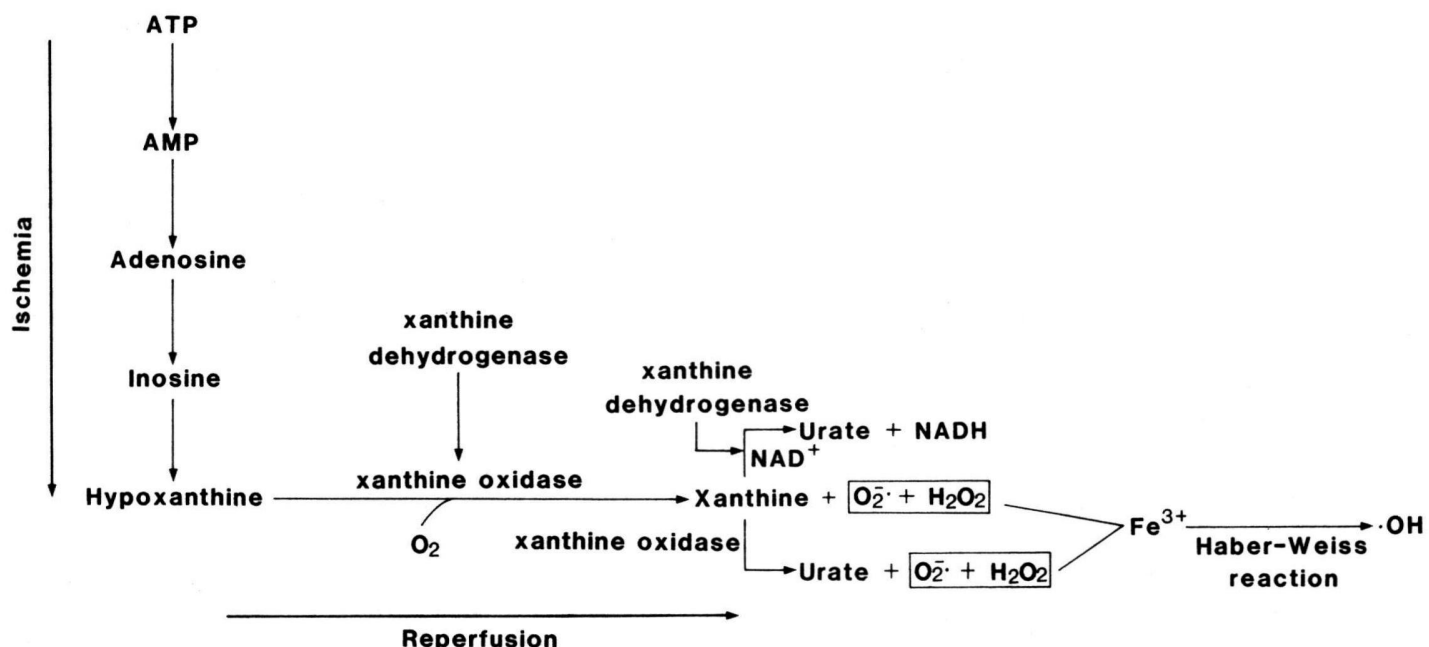

Fig. 1 The proposed mechanism for the generation of active oxygen species in ischemia-reperfusion. 
告している.

酸化的ストレスに抢ける細胞障害の直接的な機構とし て, 反応性の低い $\mathrm{O}_{2}{ }^{\top}$ p $\mathrm{H}_{2} \mathrm{O}_{2}$ 上り反応性の高い. $\mathrm{OH}$ の関与を示唆している報告も多くある.すなわち, 虚血 時にみられるアシドーシスの状態では，トランスフェリ ン,フェリチンなどの鉄結合タンパク質から $\mathrm{O}_{2}{ }^{*}$ によ り $\mathrm{Fe}^{3+}$ が還元され, $\mathrm{Fe}^{2+}$ として遊離され, $\mathrm{H}_{2} \mathrm{O}_{2}$ と反 応して・OH を生じる. この・OH が DNA, タンパク質 などを直接攻撃する一方で, 脂質と反応して脂質ラジカ ルを経て脂質ヒドロペルオキシドの生成に発展する ${ }^{6}$. これに関連して, Arroyo ら ${ }^{9)}$ は, 心筋の虚血一再灌流 時に・OH が産生されること, Das ら ${ }^{10)}$ は, 心筋ミトコ ンドリアでの・OH の生成を認めている。 また，ラジカ ルスキャベンジャ一であるジメチルスルホキシド (DMSO) やジメチルチオ尿素の処置により, 心臓の虚 血一再灌流障害が抑制されたといら報告 ${ }^{11,12)}$ もあり, $\mathrm{O}_{2}{ }^{\overline{ }}{ }^{\dagger}$ および $\mathrm{H}_{2} \mathrm{O}_{2}$ からの・ $\mathrm{OH}$ の生成そして障害に至る 経路は否定できないものと思われる.

前述したように, 虚血後, 酸素が供給されるとヒポキ サンチン, キサンチンオキシダーゼ, 酸素の三者が共存 することにより，まず最初に $\mathrm{O}_{2}{ }^{\top}$ が生じることになる. $\mathrm{O}_{2}{ }^{-}$泩生体に执いてその他, 種々の反応系に上り生成さ れるが，その生成部位は生体膜のような疎水環境より， 細胞質のよらな親水環境で生成しやすい. $\mathrm{O}_{2}{ }^{-}$は水溶液 中での寿命は短いが, 脂溶性の状態では消隇する時間は
遅いことから, hydrophilic と hydrophobic の環境下で は活性酸素の作用が異なることは十分考えられる， $\mathrm{O}_{2}{ }^{\circ}$ は, 弱酸性あるいは中性の $\mathrm{pH}$ 下でアニオンの型で存 在するが，その生体膜の透過性はほとんどないといわれ ている13)。したがって $\mathrm{O}_{2}{ }^{-}$は生成した場所で作用する か，他の活性酸素に変換されて作用することが考えられ る. 後者の考光は, 反応速度定数からみると, $\mathrm{O}_{2}{ }^{\top}{ }^{-}$自身 にはとれほど強い反応性がなく ${ }^{14)}$, 酸素障害や過酸化脂 質の生成に拈ける $\mathrm{O}_{2}{ }^{\top}$ の役割は注とんどなく，それか ら二次的に派生した活性酸素種によって反応が促進され るといわれていること年16) からも推測できる。そこで 考えられるのが $\mathrm{O}_{2}{ }^{-}$の $\mathrm{H}_{2} \mathrm{O}_{2}$ への変換である $($ 図 2 ).

活性酸素の中で, 最も反応性の高い.OH を直接に生 成する反応は生体組織細胞には存在しない。しかし,

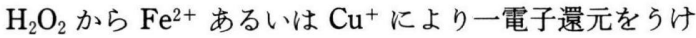
. $\mathrm{OH}$ は容易に生成される. $\mathrm{O}_{2}{ }^{\top}{ }^{{ }^{2}}$ は酸化, 還元の両作用 を有し，特に金属イオンをすみやかに還元する。これに 関して，最近になって $\mathrm{O}_{2}{ }^{-}$が鉄の細胞内貯蔵型である フェリチン分子中の $\mathrm{Fe}^{3+}$ を還元して， $\mathrm{Fe}^{2+}$ を遊離さ せることが Biemond ら ${ }^{17,18)}$ とより報告された． 細胞外 液では $\mathrm{O}_{2}{ }^{-}$は不均化反応 (dismutation) により $\mathrm{H}_{2} \mathrm{O}_{2}$ を 生成する.この $\mathrm{H}_{2} \mathrm{O}_{2}$ は $\mathrm{Fe}^{3+}$ の存在下, $\mathrm{O}_{2}{ }^{-}$との反応 (Haber-Weiss 反応 $\left.{ }^{19}\right)$ により・OH を生じる。一方，図 2 亿示したように, $\mathrm{Fe}^{2+}$ は $\mathrm{H}_{2} \mathrm{O}_{2}$ (膜の透過性は容易で ある）との反応 (Fenton 反応)を経て・OH を生じ, 脂

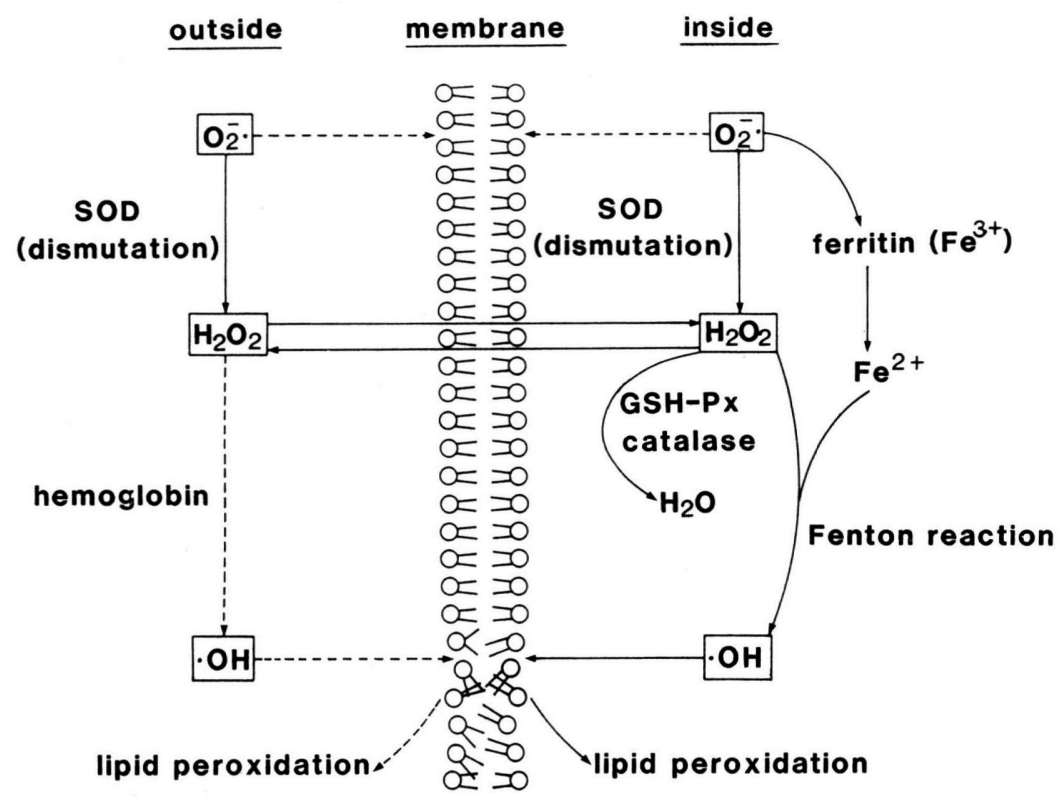

Fig. 2 Active oxygen species and lipid peroxidation. 
質過酸化反応が開始されるのが一般的現象のよらである (実線はメインルート, 破線はマイナールート $\left.{ }^{13,20)}\right)$. 生 体内の鉄イオンや銅イオンはフェリチンやセルロプラス ミンなどのタンパク質に結合した状態で保持され，容易 に $\mathrm{H}_{2} \mathrm{O}_{2}$ や脂質ヒドロペルオキシドを分解しないように なっていることからも, 細胞内での酸素障害は鉄や銅イ オンの細胞内での状態に依存しているといえるかも知れ ない。このように細胞内での活性酸素の生成機構を考え る時, $\mathrm{O}_{2}{ }^{-}$それ自身は反応性は低いが，他の活性酸素の 前駆物質の役割を果たしている可能性が大きいように思 われる.

生理的条件下では $\mathrm{O}_{2}{ }^{-}$を発生する機構は組織液, 血 液中や細胞内顆粒にて酵素系により行われる。白血球は 好中球やマクロファージを含むが，いずれにおいても， ある刺激により NAD (P) H オキシダーゼの活性が高ま り $\mathrm{O}_{2}{ }^{\bar{*}}$ が生成される ${ }^{21)}$. この $\mathrm{O}_{2}{ }^{\bar{*}}$ は殺菌作用を示す原 動力であるが，過剰の生成は炎症を引き起こすことにな る. ミトコンドリアでは, 電子伝達系により ATP を合 成する過程で $\mathrm{O}_{2}{ }^{*}$ を生成する。 これは, $\mathrm{CoQ}$ の一電子 還元で生じた $\mathrm{CoQ}^{`}$ により $\mathrm{O}_{2}$ が一電子還元を受けて

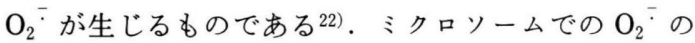
生成は NADPH 依存性チトクローム P450 還元酵素と 関連している. ブロメラインのよらなタンパク質分解酵 素でミクロソームを処理した場合と, 界面活性剂で処理 して得たチトクローム P450 還元酵素とでは $\mathrm{NADPH}$ 存在下に和ける $\mathrm{O}_{2}{ }^{\top}$ の生成に差があるといわれてい る ${ }^{23,24)}$. 後者の場合, ミクロソームでの $\mathrm{O}_{2}{ }^{\circ}$ の生成は $\mathrm{NADPH}$ 依存性チトクローム P450 還元酵素と P450 が リンクして, NADPH から放出された一電子が $\mathrm{O}_{2}$ に渡 され一電子還元をらけて $\mathrm{O}_{2}{ }^{\top}$ が生成される.

さて, 生体組織細胞で発生した活性酸素, フリーラジ カルの消去系はどのような機構で行なわれるであろら か. 活性酸素やフリーラジカルの消去は, 細胞レベルで は酵素系に依存している場合が多い上らに思われる. $\mathrm{O}_{2}{ }^{*}$ や $\mathrm{H}_{2} \mathrm{O}_{2}$ を消去する酵素系がよくリンクしていると ころは，活性酸素の効果は最小限にとどめることができ る、酵素としてはSOD があり，この酵素は細胞質に存 在する $\mathrm{Cu}-\mathrm{ZnSOD}$ とミトコンドリアに存在する Mn$\mathrm{SOD}$ の 2 種が主なものである. 作用は両者とも $\mathrm{O}_{2}{ }^{-}$を 消去して $\mathrm{H}_{2} \mathrm{O}_{2}$ にし, いわゆるラジカルの捕捉, 消去を 目的とする.グルタチオンペルオキシダーゼ (GSH$\mathrm{Px}$, 細胞質やミトコンドリアに存在 $)$, カタラーゼ (ペ ルオキソソームに存在) は $\mathrm{H}_{2} \mathrm{O}_{2}$ を分解し, ラジカル $(\cdot \mathrm{OH})$ の発生を抑制する.したがって, これらの酵素
は抗酸化酵素ともいわれている.

ミトコンドリア内で発生した $\mathrm{O}_{2}{ }^{\bar{*}}$ は, Mn-SOD (内膜 に存在)により $\mathrm{H}_{2} \mathrm{O}_{2}$ に変換される。この $\mathrm{H}_{2} \mathrm{O}_{2}$ は GSH-Px により $\mathrm{H}_{2} \mathrm{O}$ に分解される. $\mathrm{H}_{2} \mathrm{O}_{2}$ は容易に膜 を通過するのでミトコンドリア外に放出された $\mathrm{H}_{2} \mathrm{O}_{2}$ は ペルオキソソームに存在するカタ.ラーゼにより, また細 胞質に存在する GSH-Pxにより消去される．ただこの 場合, 低濃度の $\mathrm{H}_{2} \mathrm{O}_{2}$ に対しては GSH-Px が作用し, 高濃度の $\mathrm{H}_{2} \mathrm{O}_{2}$ はカタラーゼによって消去されるといわ れている ${ }^{25)}$. ミクロソームにはミトコンドリアと異なり， $\mathrm{O}_{2}{ }^{-}$や $\mathrm{H}_{2} \mathrm{O}_{2}$ を消去する酵素系が存在しないため, ミク ロソームで発生した $\mathrm{O}_{2}{ }^{-}$や $\mathrm{H}_{2} \mathrm{O}_{2}$ は膜外に放出される. そこで $\mathrm{O}_{2}{ }^{-}$は $\mathrm{Cu}-\mathrm{ZnSOD}$ により $\mathrm{H}_{2} \mathrm{O}_{2}$ となり, ついで $\mathrm{H}_{2} \mathrm{O}_{2}$ は GSH-Px により消去される.

$\mathrm{SOD}, \mathrm{GSH}-\mathrm{Px}$, カタラーゼの活性酸素消去に対する 作用は，その環境に応じて役割を分担しているように思 える. 例えば, 高圧酸素下, ビタミン $\mathrm{E}$ 欠乏動物の肝 や肺で生成した酸素種はほとんど GSH-Pxによって分 解され, カタラーゼは効果がないこと ${ }^{26)}$, またキサンチ ンーキサンチンオキシダーゼ系で $\mathrm{O}_{2}{ }^{\top}$ を発生させ ラット肺に SOD を注入すると急性肺傷害や浮腫は抑制 されるが，カタラーゼでは効果が認められないこと27) が報告されている.このことは, これらの酵素がある場 合には相補的に作用し，また一方ではそれぞれの酸素種 の発生源に対して, その機能を分担していることを示唆 しているものと考えられるが，その機序はまだ明らかに されていない.

最近, SOD の誘導体が開発された. SOD は血中に投 与してもすぐに消失してしまい, 効果が持続しない.こ の欠点を克服するために化学修飾した SMA-SOD (スチ ルマレイン酸エステル誘導体) が組織内 $\mathrm{pH}$ 低下部位 （虚血時, 炎症部など) に集まり, SODよりも血中の活 性寿命が長いことから酸化的ストレスに有効であるとい われている28).この SMA-SOD は細胞外空間における $\mathrm{O}_{2}{ }^{\top}$ の消去を目的として開発されたものと考えられる が, 一方, 細胞内に拈ける活性酸素の細胞毒性を消去す るには外因性の SOD はェンドサイトーシスで細胞内に 取り込まれる必要がある29). このことより, SODを含 む活性酸素消去系に関与する外因性の酵素が, in vivo で有効に作用する機構解明およびいろいろな角度からの 酵素誘導体の開発が待たれる.

一方, 抗酸化作用を有する化合物（抗酸化剤）として は脂溶性化合物と水溶性化合物があり, 前者にはビタミ ン $\mathrm{E}$, ユビキノン, カロチノイドなどがある. 後者はア 
スコルビン酸（鉄イオンと共存する場合はラジカル生成 に働く), グルタチオン, 尿酸などである.これらの化 合物は, ほとんどがラジカルの捕捉, 消去作用を有し, ラジカルの発生段階は抑制しない.

抗酸化剂を使用する時は脂溶性（膜レベルで作用） か, 水溶性 (細胞質, 細胞外液) かを良く見極めて実験 に供しないと，ただその結果のみを容易に判断すること は危険である. 発生するラジカルが膜レベルか, 細胞質, 血中レベルかで活性酸素の捕捉, 消去の効果に差が生じ ることが予想される.

その他, 生体内の抗酸化物質を修飾した抗酸化性薬物 および天然物などが開発されているがここでは省略し， 優れた最近の文献を参照していただきたい30).

\section{III. 過酸化脂質の生体組織での生成と消去}

生体内で生成される過酸化脂質, $\mathrm{LOOH}$ の基質は主 として膜リン脂質の二重結合を 2 個以上有する脂肪酸 (多不飽和脂肪酸) である. この膜リン脂質は生体膜構 成成分の複合脂質である，脂肪（トリグリセリド）と異 なる点はグリセロール骨格の末端の水酸基 1 個が脂肪酸 のエステル結合でなく, リン酸と結合していることであ る.

一般に膜リン脂質が少々のアルカリや酸に対して抵抗 力を示すのは, 構造的にみてグリセリド部で疎水性を示 し，ホスホリルコリン，あるいはエタノールアミン部で 親水性を示すいわゆる両親媒性の化合物であり, 外部か らのアルカリに対しては, コリンやェタノールアミン部 のー- $\mathrm{N}^{+}$一が, 酸に対してはリン酸部の- - - がう
けて，その作用を弱めている.

不飽和脂質は空気中に放置すると酸素を吸収して着色 し，ついには黒色のタール様物質に変わり不快臭を発す る.この過程が一般に脂質の自動酸化と呼ばれる現象で あるが，その機構はきわめて複雑である．生体で起こる 脂質の過酸化反応にはいろいろなファクターが要求され る.

過酸化脂質の形成機構は大別すると 2 つる. 一つは フリーラジカルの開始剤によって促進される非酵素的な 過酸化反応であり，他は主としてミクロソームで行なわ れる NADPH 依存性の酵素による過酸化反応で, 両者 とも分子状の酸素を必要とする. 生体組織での脂質過酸 化は主としてこの 2 つ系で行なわれるが，その基質は 膜リン脂質であり, 過酸化現象が最も起こりやすいのは, この脂質に富んでいるミトコンドリアやミクロソームな ど膜レベルでの反応が主たる場所である ${ }^{31,32)}$.

膜リン脂質からホスホリパーゼ $\mathrm{A}_{2}$ の作用により放出 された脂肪酸 (アラキドン酸) は, 酵素的に酸化される 場合がある. 図 3 に示したよらに, アラキドン酸からシ クロオキシゲナーゼ, リポキシゲナーゼ系を経て, 場所 的な違いは別として, 生成される過酸化脂質 $\left(\mathrm{PGG}_{2}\right.$, HPETE) はアラキドン酸カスケードの中間体として存 在するが，それらが膜障害をきたすとは考えられない. Gaudet $5^{33)}$ は, 脳虚血後に血流を再開すると脳内プロ スタグランジン類 $\left(\mathrm{E}_{2}, \mathrm{~F}_{2 \alpha}, \mathrm{D}_{2}, \mathrm{I}_{2}\right)$ が著明に増加するこ とを認めた。 また, ロイコトリェンも血流再開後に急増 することが明らかになった ${ }^{34)}$ ，このことは，虚血中に蓄 積されたアラキドン酸の一部がシクロオキシゲナーゼや

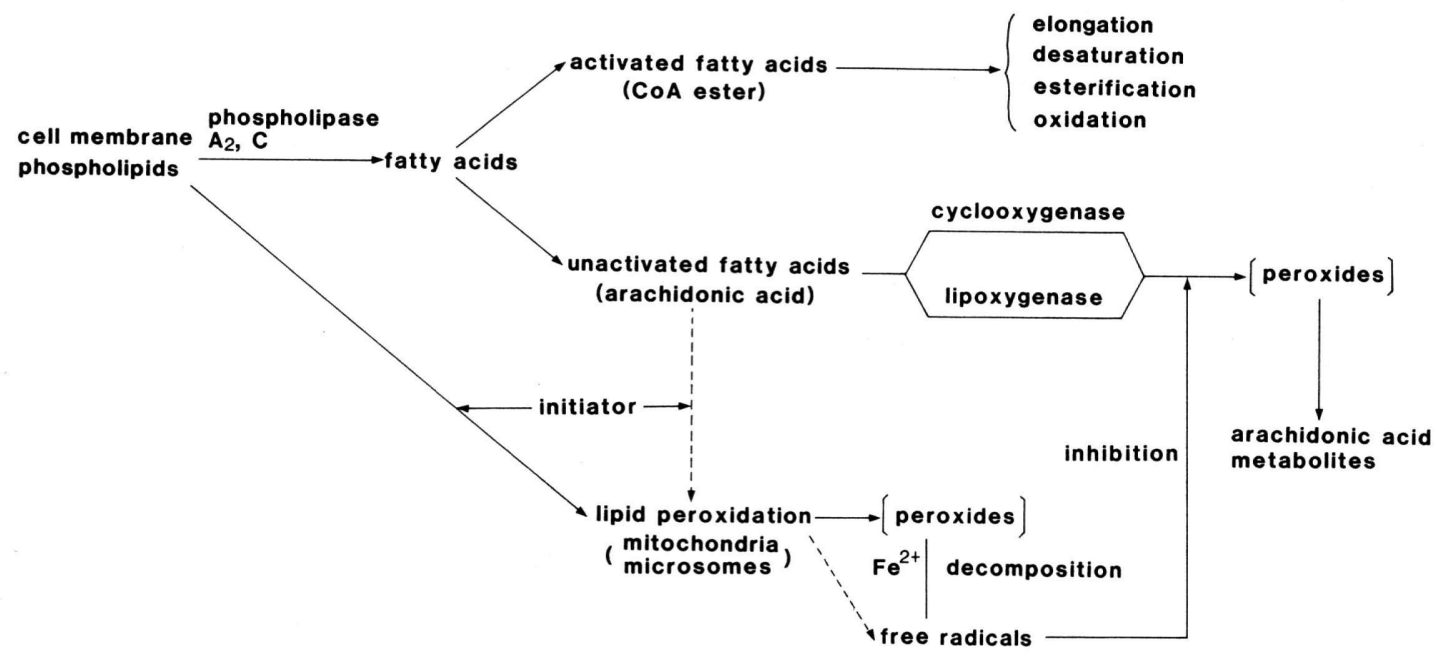

Fig. 3 Lipid peroxides and free radicals from membrane phospholipids. 
リポキシゲナーゼにより血流再開後に供給される酸素と 反応して過酸化物となり,さらにその後の代謝経路が賦 活されることを示唆しているものと思われる. もしプロ スタグランジンの生成過程 $\left(\mathrm{PGG}_{2} \rightarrow \mathrm{PGH}_{2}\right)$ で発生する 酸素ラジカルで膜障害が引き起こされるとすれば両酵素 による代謝系は進行しなくなる、アラキドン酸カス ケードに拈ける過酸化脂質の影響は, in vitro に比し ${ }^{35)}$, in vivo での実験系はいろいろな因子が関与するのでそ の機構の証明はむずかしい. 現在のところでは膜レベル に扰いて, またミトコンドリアやミクロソームの脂質過 酸化反応から誘導されるフリーラジカルによって膜障害 が引き起こされると考えるのが一般的であろう.

それでは膜レベルに拈ける脂質過酸化反応を促進する 因子は何であろらか、結論的にみると, 生体組織では $\mathrm{O}_{2}{ }^{\overline{ }}, \mathrm{H}_{2} \mathrm{O}_{2}, \mathrm{Fe}^{2+}$ の 3 つの相互作用により・OH が生成 され, その後脂質過酸化反応が促進されるものと推定で きる. 前項で述べたように活性酸素種の中でも・OH が 過酸化現象のキャスティングボートを握っているように 思われるが、そこに至るまでが現在はっきりしていない， 図 4 に示されるよらに, 膜りン脂質から脂質ラジカルに 至るまでの機構が複雑である.脂質過酸化反応は膜リン 脂質の 2 位の多不飽和脂肪酸からの水素の引き抜きに始 まる.すなわち，二重結合に挾まれたメチレン基の水素 が最も引き抜かれやすく, その後, リン脂質ヒドロペル オキシド (PL-OOH) を形成する.つぎに活性化された ホスホリパーゼ $\mathrm{A}_{2}$ の作用により脂肪酸ヒドロペルオキ シド $(\mathrm{FA}-\mathrm{OOH})$ が遊離される ${ }^{36}$ 38). も5一つの考壳ら れる過程は, 過酸化反応の最初の段階でホスホリパーゼ $\mathrm{A}_{2}$ が活性化され脂肪酸が遊離されることである(図 3 ). その脂肪酸に開始剂が働き脂質ラジカルが生成さ れる経路である.しかしいずれにしても脂質ラジカルは 形成されるが，そこに至るまでのホスホリパーゼ $\mathrm{A}_{2}$ の
挙動が問題である.

膜リン脂質中の多不飽和脂肪酸鎖が過酸化をうける と, 極性の $-\mathrm{OOH}$ 基が生成され, 脂肪酸鎖の疎水的結 合は弱くなり, 膜のコンホメーションが変化し, 流動性 が増す、その結果, ホスホリパーゼ $\mathrm{A}_{2}$ が，基質である 膜リン脂質に接近しやすくなり, $\mathrm{LOOH}$ を切り離す.

遊離された LOOH はつぎのよらにグルタチオンと GSH-Px により, 脂質アルュール (LOH) に分解され $3^{39)}$.

$$
\mathrm{LOOH}+2 \mathrm{GSH} \longrightarrow \mathrm{LOH}+\mathrm{H}_{2} \mathrm{O}+\mathrm{GSSG}
$$

一方, $\mathrm{LOOH}$ は鉄や銅などの遷移金属イオンが存在 するとつぎのように, LO・や LOO·を生成し, 新たな 脂質過酸化反応の開始剂になり連鎖反応が進行する.

$$
\begin{aligned}
& \mathrm{LOOH}+\mathrm{Fe}^{2+} \longrightarrow \mathrm{LO} \cdot+\mathrm{OH}^{-}+\mathrm{Fe}^{3+} \\
& \mathrm{LOOH}+\mathrm{Fe}^{3+} \longrightarrow \mathrm{LOO} \cdot+\mathrm{H}^{+}+\mathrm{Fe}^{2+}
\end{aligned}
$$

つぎに体内で生成された過酸化脂質を消去する機構と しては前述した GSH-Px, また, 膜レベルではビタミン $\mathrm{E}$ やユビキノンがある. 酵素の場合はラジカルの発生を

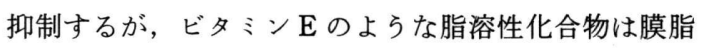
質で生じた LOO·, LO・を捕捉し, ラジカルの連鎖反応 を止める作用がある.

最近 Maiorino ら ${ }^{40)}$ は新しいSe 依存性の GSH-Px を見つけた。この酵素はビタミン $\mathrm{E}$ の共存下, 基質と してリン脂質の多不飽和脂肪酸の過酸化脂質に直接作用 して脂質アルコールを生じるもので, ホスホリパーゼ $\mathrm{A}_{2}$ によって切り離される前に, あるいは $\mathrm{Fe}^{2+}$ が作用 して LO・を形成する前に, 過酸化脂質はこの酵素によ り, リン脂質から消去されることを報告している. この GSH-Px とビタミン $\mathrm{E}^{41)}$ にホスホリパーゼ $\mathrm{A}_{2}$ がどの ように関与して, 過酸化りン脂質を消去してゆくかその 機序解明が待たれる.

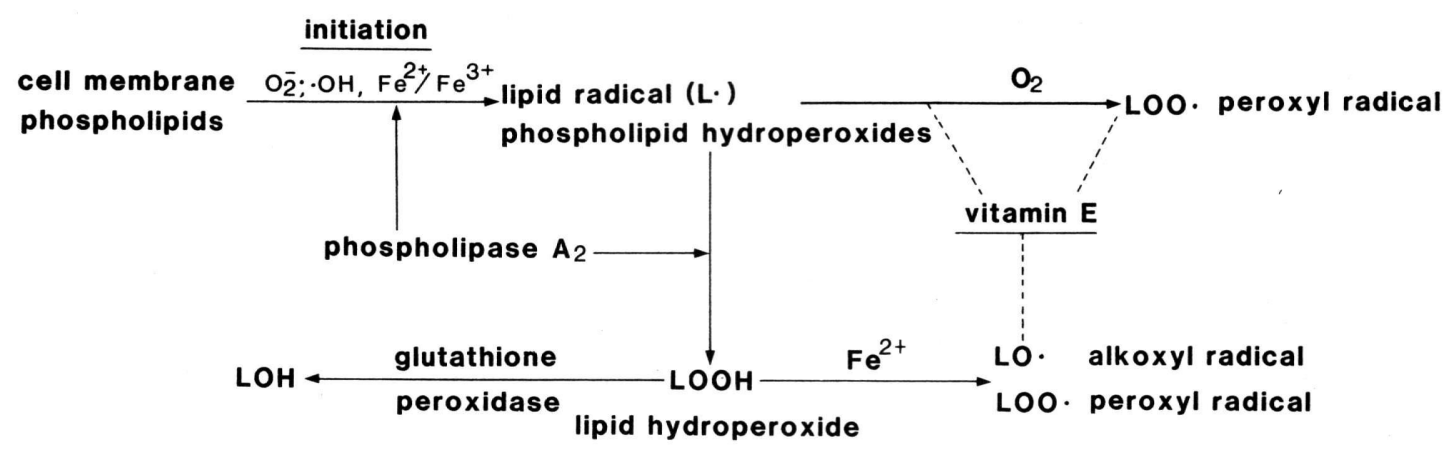

Fig. 4 The relationship between lipid radical and phospholipase $A_{2}$. 


\section{N.おわりに}

活性酸素一過酸化脂質の生体組織における生成と消去 機構について概略を述べた. 1985年以来, 活性酸素の生 体に打ける挙動, 影響について数多くの報告がありま た臨床面からも大きな関心が寄せられているが, その結 果についてはほとんどが現象面からの解釈で本質的なも のは未解明である。それはこの方面の研究では, in vitro の成績がそのまま in vivo の実験に適用できない からであろら。また脂質過酸化反応を最初に引き起こす 活性種が何であるかについては様々な説がある. Bast and Steeghs ${ }^{42)}$ はラット肝ミクロソームの NADPH 依 存の脂質過酸化反応に拈いて・OH の生成を認めつつ も，それは開始剤にならないという。つまり, 反応系に カタラーゼあるいは捕捉剤である DMSO を添加しても 脂質過酸化は抑制されず，過酸化の開始剤には他の活性 種の存在を示唆している.これに関連して, 肝ミクロ ソームにおける脂質過酸化は鉄一酸素錯体であるペル フェリルイオン $\left(\mathrm{Fe}^{2+}-\mathrm{O}_{2}\right)$ により開始されることが報 告されている43)。このペルフェリルイオンは $\mathrm{ADP}-\mathrm{Fe}^{3+}$ が肝ミクロソームの NADPH-チトクローム P450 還元 酵素の作用により NADPH から電子を受けて ADP$\mathrm{Fe}^{2+}$ となり, 分子状酸素と結合してペルフェリルイオ ンが形成されるという．このように，脂質過酸化を引き 起こす活性種は特定できず, 反応の場や状況に応じて変 化すると思われる．それぞれの活性種がどこで生成され るのか, その場がきわめて重要である.

膜の脂質過酸化の促進により, いろいろな障害, たと えば酵素活性の低下や生理活性物質の減少などさまざま な現象が考兄られ, 種々の疾病の誘因になる可能性は十 分考兄られる. しかし, 活性酸素により特異的に障害を きたす臓器特異性は異物を投与しない限り生理的には考 えられない, 生体で脂質過酸化が行われる場合, どの細 胞顆粒画分が特に障害をらけるか，またその反応を部位 ごとに検知する方法は現在のところまだ確立されていな い. 当然, 防御も部位ごとに行らことは望めないので, 総合的な抗酸化剤を適用することが現実的であろう.

活性酸素誘導による膜障害が，その発生と消去のバラ ンスの崩れから出現することが一般的に認められてい る. この関係を如実に示しているのが近年, 特に話題と なっている虚血一再灌流の研究であろう。この実験系は 基礎と臨床の接点を示しているょらに思われるが, SOD といら酵素を用いて体内の活性酸素の挙動を判断 することに無理がある。それはSOD やカタラーゼが高
分子タンパクのため膜の透過性はなく, どのよらな機序 で細胞内の活性酸素を消去するかといらことは未解決で ある。一方, 虚血一再灌流時の膜障害に㧊けるホスホリ パーゼ $\mathrm{A}_{2}$ の働きも無視できない，再灌流に伴っての $\mathrm{Ca}^{2+}$ の流入がホスホリパーゼ $\mathrm{A}_{2}$ の活性を高めて膜り ン脂質の分解を促すからである.

今後, 活性酸素一過酸化脂質の一連の反応系にかかわ る酵素, 発生するラジカルを直接証明する手段, 定量 的44)な議論を進めないかぎり, 活性酸素一過酸化脂質 の生体に打ける役割が現象面から過大評価される危険性 があることを十分認識する必要があろら。

\section{文献}

1) Granger, D.N., Rutili, G. and McCord, T.M.: Superoxide radicals in feline intestinal ischemia. Gastroenterology 81, 22 29 (1981)

2) Wajner, M. and Harkness, R.A.: Distribution of xanthine dehydrogenase and oxidase activities in human and rabbit tissues. Biochim. Biophys. Acta 991, 79 84 (1989)

3) Mittnacht, S., Jr. and Farber, J.L.: Reversal of ischemic mitochondrial dysfunction. J. Biol. Chem. 256, 3199 3206 (1981)

4) Kawasaki, T., Hayashi, K., Marubayashi, S. and Dohi, K.: Preservation of ischemic rat liver mitochondrial functions, energy metabolism and viability of ischemic liver by coenzyme $\mathrm{Q}_{10}$ pretreatment. In Biomedical and Clinical Aspects of Coenzyme Q, Edited by Folkers, K. and Yamamura, Y., Vol. 3, p. 337 348, Elsevier, Amsterdam (1981)

5) Marubashi, S., Dohi, K., Yamada, K. and Kawasaki, T.: Changes in the levels of endogenous coenzyme Q homologs, $\alpha$-tocopherol, and glutathione in rat liver after hepatic ischemia and reperfusion, and the effect of pretreatment with coenzyme $Q_{10}$. Biochim. Biophys. Acta 797, $1 \sim 9$ (1984)

6) Halliwell, B.: Oxidants and human disease: some new concepts. FASEB J. 1, 358 364 (1987)

7) Nordström, G., Seeman, T. and Hasselgren, P.O.: Beneficial effect of allopurinol in liver ischemia. Surgery 97, 679 684 (1985)

8) Yoshikawa, T., Ueda, S., Naito, Y., Takahashi, S., Oyamada, H., Morita, Y., Yoneta, T. and Kondo, M.: Role of oxygen-derived free radicals in gastric mucosal injury induced by ischemia or ischemiareperfusion in rats. Free Radic. Res. Commun. 7, 285 291 (1989)

9) Arroyo, C.M., Kramer, J.H., Dickens, B.F. and Weglicki, W.B.: Identification of free radicals in myocardial ischemia/reperfusion by spin trapping 
with nitrone DMPO. FEBS Lett. 221, 101 104 (1987)

10) Das, D.K., George, A., Liu, X. and Rao, P.S.: Detection of hydroxyl radical in the mitochondria of ischemic reperfused myocardium by trapping with salicylate. Biochem. Biophys. Res. Commun. 165, 1004 1009 (1989)

11) Ganote, C.E., Sims, M. and Safavi, S.: Effects of dimethylsulfoxide (DMSO) on the oxygen paradox in perfused rat hearts. Am. J. Pathol. 109, 270 276 (1982)

12) Bolli, R., Zhv, W.X., Hartley, C.J., Michael, R.C. and Roberts, R.: Attenuation of dysfunction in the postischemia stunned myocardium by dimethylthiourea. Circulation 76, 458 468 (1987)

13) Takahashi, M. and Asada, K.: Superoxide anion permeability of phospholipid membranes and chloroplast thylakoids. Arch. Biochem. Biophys. 226, 558 566 (1983)

14）二木鋭雄：活性酸素とはなにか。活性酸素, 八木 國夫, 中野 稔監修, 二木鋭雄, 島崎弘幸編集, p. 1 32, 医歯薬出版, 東京 (1987)

15) Thomas, M.J., Mehl, K.S. and Pryor, W.A.: The role of superoxide in xanthine oxidase-induced autooxidation of linoleic acid. J. Biol. Chem. 257, $8343 \sim 8347$ (1982)

16) Bielski, B.H., Arudi, R.L. and Sutherland, H.W.: A study of the reactivity of $\mathrm{HO}_{2} / \mathrm{O}_{2}^{-}$with unsaturated fatty acids. J. Biol. Chem. 258, 4759 4761 (1982)

17) Biemond, P., Van Eijk, H.G., Swaak, A.J.G. and Koster, J.F.: Iron mobilization from ferritin by superoxide derived from stimulated polymorphonuclear leukocytes. Possible mechanism in inflammation diseases. J. Clin. Invest. 73, 1576 1579 (1984)

18) Biemond, P., Swaak, A.J.G., Van Eijk, H.G. and Koster, J.F.: Superoxide dependent iron release from ferritin in inflammatory diseases. Free Radic. Biol. Med. 4, 185 198 (1988)

19) Granger, D.N.: Role of xanthine oxidase and granulocytes in ischemia-reperfusion injury. Am. J. Physiol. 255, H1269 H1275 (1988)

20) Lynch, E. and Fridovich, I.: Effects of superoxide on the erythrocyte membrane. J. Biol. Chem. 253, 1838 1845 (1978)

21) Wakeyama, H., Takeshige, K., Takayanagi, R. and Minakami, S.: Superoxide-forming NADPH oxidase preparation of pig polymorphonuclear leukocytes. Biochem. J. 205, 593 601 (1982)

22) Turrens, J.F., Alexandre, A. and Lehninger, A. L.: Ubisemiquinone is the electron donor for superoxide formation by complex III of heart mitochondria. Arch. Biochem. Biophys. 237, 408 414 (1985)

23) Ingelman-Sundberg, $M$. and Johansson, I.: Mechanisms of hydroxyl radical formation and ethanol oxidation by ethanol-inducible and other forms of rabbit liver microsomal cytochromes P-450. J. Biol. Chem. 259, 6447 6458 (1984)

24) Minakami, H., Arai, H., Nakano, M., Sugioka, K., Suzuki, S. and Sotomatsu, A. : A new and suitable reconstructed system for NADPH-dependent microsomal lipid peroxidation. Biochem. Biophys. Res. Commun. 153, 973 978 (1988)

25) Flohé, L. and Brand, I.: Kinetics of glutathione peroxidase. Biochim. Biophys. Acta 191, 541 549 (1969)

26) Nishiki, K., Jamieson, D., Oshino, N. and Chance, B.: Oxygen toxicity in the perfused rat liver and lung under hyperbaric conditions. Biochem. J. 160, 343 355 (1976)

27) Halliwell, B. and Gutteridge, J.M.C.: Oxygen toxicity, oxygen radicals, transition metals and disease. Biochem. J. 219, 1 14 (1984)

28）井上正康, 渡辺信和：虚血性心疾患と SOD 誘導体. モダンメディシン 17, 84〜87 (1988)

29) Kyle, M.E., Nakae, D., Sakaida, I., Miccadei, S. and Farber, J.L.: Endocytosis of superoxide dismutase is required in order for the enzyme to protect hepatocytes from the cytotoxicity of hydrogen peroxide. J. Biol. Chem. 263, 3784 3789 (1988)

30）福沢健治, 高石喜久：抗酸化剤. 活性酸素・フリーラ ジカル 1, 55〜70 (1990)

31）藤田 直：過酸化脂質と薬物代謝. 過酸化脂質と疾 患, 八木國夫, 五島雄一郎編集, p. $65 \sim 72$, 医学書 院, 東京 (1981)

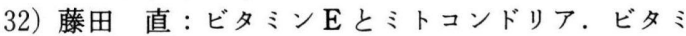
ン $\mathrm{E}$ 一基礎と臨床一, 福場博保, 美濃 真監修, 五十嵐脩編集, p. 116 122, 医歯薬出版, 東京 (1985)

33) Gaudet, R.J., Alam, I. and Levine, L.: Accumulation of cyclooxygenase products of arachidonic acid metabolism in gerbil brain during reperfusion after bilateral common carotid artery occlusion. J. Neurochem. 35, 653 658 (1980)

34) Moskowitz, M.A., Kiwak, K.J., Hekimian, K. and Levine, L.: Synthesis of compounds with properties of leukotrienes $\mathrm{C}_{4}$ and $\mathrm{D}_{4}$ in gerbil brains after ischemia and reperfusion. Science 224, 886 889 (1984)

35) Fujimoto, Y. and Fujita, T.: Effects of lipid peroxidation on prostaglandin synthesis in rabbit kidney medulla slices. Biochim. Biophys. Acta 710, 82 86 (1982)

36) Yasuda, M. and Fujita, T.: Effect of lipid peroxidation on phospholipase $\mathrm{A}_{2}$ activity of rat liver mitochondria. Japan. J. Pharmacol. 27, 429 435 (1977)

37) Sevanian, A., Stein, R.A. and Mead, J.F.: Metabolism of epoxidized phosphatidylcholine by phospholipase $\mathrm{A}_{2}$ and epoxide hydrolase. Lipids 16, 781 789 (1981) 
38) Sevanian, A. and Kim, E.: Phospholipase $\mathrm{A}_{2}$ dependent release of fatty acids from peroxidized membranes. J. Free Radic. Biol. Med. 1, 263 271 (1985)

39) Sevanian, A., Mvakkassah-Kelly, S.F. and Montestruque, S.: The influence of phospholipase $\mathrm{A}_{2}$ and glutathione peroxidase on the elimination of membrane lipid peroxides. Arch. Biochem. Biophys. 223, 441 452 (1983)

40) Maiorino, M., Coassin, M., Roveri, A. and Ursini, F.: Microsomal lipid peroxidation: Effect of vitamin $\mathrm{E}$ and its functional interaction with phospholipid hydroperoxide glutathione peroxidase. Lipids 24, 721 726 (1989)
41) Douglas, C.E., Chan, A.C. and Choy, P.C.: Vitamin $\mathrm{E}$ inhibits platelet phospholipase $\mathrm{A}_{2}$. Biochim. Biophys. Acta 876, 639 645 (1986)

42) Bast, A. and Steeghs, M.H.M.: Hydroxyl radicals are not involved in NADPH dependent microsomal lipid peroxidation. Experientia 42, 555 556 (1986)

43) Minotti, G. and Aust, S.D.: The requirement for iron (III) in the initiation of lipid peroxidation by iron (II) and hydrogen peroxide. J. Biol. Chem. 262, 1098 1104 (1987)

44) Gutteridge, J.M. and Halliwell, B.: The measurement and mechanism of lipid peroxidation in biological systems. Trends Biochem. Sci, 15, 129 135 (1990)

Abstract-Formation and removal of active oxygen species and lipid peroxides in biological systems. Tadashi FUJITA and Yohko FUJIMOTO (Department of Hygienic Chemistry, Osaka University of Pharmaceutical Sciences, Matsubara, Osaka 580, Japan). Folia pharmacol. japon. 99, 381 389 (1992) The mechanisms of formation and removal of active oxygen species and lipid peroxides in biological systems have been briefly reviewed. Cytotoxic active oxygen species can be classified into two types: (a) radical species such as $\mathrm{O}_{2}{ }^{-}$(superoxide) and $\mathrm{HO} \cdot$ (hydroxyl radical) and (b) non-radical species such as $\mathrm{H}_{2} \mathrm{O}_{2}$ (hydrogen peroxide) and ${ }^{1} \mathrm{O}_{2}$ (singlet oxygen). The direct or indirect attack of active oxygen species on polyunsaturated fatty acids, essential constituents of biological membranes, has been shown to result in the formation of a number of peroxidative lipid breakdown-products: LOOH (lipid hydroperoxide), $\mathrm{LOO}$ - (lipid peroxyl radical) and $\mathrm{LO} \cdot($ lipid alkoxyl radical). The lipid peroxide decomposition is probably dependent on the presence of ferric-ferrous ions. These processes are called lipid peroxidation reactions. In recent years, there has been a renewed interest in the role played by lipid peroxidation in many disease states. The multiple lines of defense against toxic oxygen intermediates consist of enzymatic systems, glutathione peroxidase, catalase and superoxide dismutase, and furthermore involves antioxidant capacities such as those of vitamin $\mathrm{E}$ and vitamin $\mathrm{C}$. In biological systems, there are naturally occurring lipid-soluble (vitamin $\mathrm{E}$ and ubiquinone) and water-soluble (vitamin $\mathrm{C}$, reduced glutathione and uric acid) antioxidants. Therefore, so long as homeostasis is maintained between the rate of radical generation and the rate of radical dissipation, the cellular generation of radicals may not be harmful. In contrast, this balance can be disturbed if cellular defenses are decreased or if there is a significant increase in the flux of radical generation. Once lipid peroxidation is initiated, the reactive intermediate formed induces cell damage. However, the mechanism of initiation of the lipid peroxidation process in biological systems is still uncertain. 